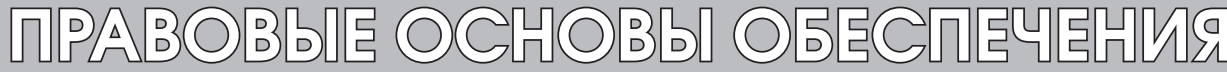 HALИOHАИЬНЙ БЕЗОПАСНОСТИ
}

УДК 32.019.52

ДОМАКОВ ВЯЧЕСЛАВ ВЕНИАМИНОВИЧ,
МАТВЕЕВ АЛЕКСАНДР ВЛАДИМИРОВИЧ,
МАТВЕЕВ ВЛАДИМИР ВЛАДИМИРОВИЧ

\section{ПРАВОВЫЕ ПРЕДПОСЫЛКИ НАЦИОНАЛЬНОЙ ТРАГЕДИИ В ТОРГОВО-РАЗВЛЕКАТЕЛЬНОМ ЦЕНТРЕ «ЗИМНЯЯ ВИШНЯ» Г. КЕМЕРОВО}

\begin{abstract}
АННОТАЦИЯ
В статье кратко описаны последствия национальной трагедии, произошедшей 25 марта 2018 г. в торговоразвлекательном центре «Зимняя вишня» г. Кемерово, и оперативно принятые по ним меры. Следственные действия предложено дополнить рассмотрением правовых предпосылок, которые привели к произошедшей трагедии и, естественно, дать варианты совершенствования правления.

Отмечено, что шоковое состояния населения не позволило сразу же обратить внимание именно на правовые предпосылки, определившие бездействие должностных лиц властных структур, которые обязаны были в соответствии с действующим законодательством осуществлять «профилактику» такого рода правонарушений в РФ.

Дан анализ действий «субъектов профилактики правонарушений» в РФ. Показано, что власть, представляющая собой «право, силу и волю над чем-либо, свободу действий и распоряжений, начальствование», в силу отсутствия обратной связи в принципе не может быть гарантирована от грубых ошибок, число которых в этой ситуации может быть уменьшено только за счет гениальности правителя. Причиной этого можно назвать делегирование функций и отсутствие контроля их исполнения в социальных институтах, начиная с Администрации Президента РФ, которая, «содействуя», т. е. «соучаствуя, помогая ... в каком-либо деле» Президенту РФ, вполне по законным основаниям при желании может разрешать проблемы обратившихся граждан самостоятельно. Оправданием этому можно считать сочетание во властных структурах функций «органа власти» и «юридического лица», занимающегося извлечением прибыли, которое ведет «к вседозволенности социального института, его должностных лиц и уничтожению индивида».

Предложено с учетом реальной постоянно меняющейся социальной среды перейти к управлению на основе принципа обратной связи. Материальной основой реализации управления на основе принципа «обратной связи» должно стать новое представление о собственности, как сложном объекте, включающем в себя объекты и субъекты собственности, отношения субъектов собственности к объектам собственности, а также отношения между субъектами собственности по поводу образования, накопления, отчуждения (захвата), присвоения, обмена или мены их, охраны, обороны (защиты), распределения и перераспределения объектов собственности и иных отношений. Поскольку собственник относится к объектам собственности как к своим, как к принадлежащим им, и соответственно - несобственник к ним как к чужим, не принадлежащим им, то для устранения такой правовой коллизии предложено, сохранив частную собственность, перейти в рамках ч. 1 ст. 244 ГК РФ, к публичной собственности, в рамках которой каждый гражданин становится сособственником без выделения его доли. В этом случае правитель с сохранением всех его привилегий и, используя принцип разделения труда и специализации, приобретает право только пользоваться, т. е. получать, извлекать пользу из объекта собственности и управлять (распоряжаться), т. е. создавать условия для извлечения максимально полезных свойств из объекта собственности в интересах и общества и его предприимчивой части, но без права определять их судьбу; нести оговоренное с собственниками бремя по содержанию переданных ему объектов собственности, не нарушать права собственников и третьих лиц и отвечать за неисполнение обязанностей, за ненадлежащее исполнение обязанностей, за ненадлежащую реализацию своих прав.
\end{abstract}

Ключевые слова: правовые предпосылки; национальная трагедия; правление; управление; профилактика; собственность; частная собственность; публичная собственность; неприкосновенность; делегирование функций; узаконенное смешение функций; вседозволенность. 


\title{
RIGHTFUL PREMISSES FOR THE NATIONAL TRAGEDY IN THE «WINTER CHERRY» SHOPPING MALL, KEMEROVO
}

\begin{abstract}
The article briefly describes the consequences of the national tragedy that took place on March 25, 2018 in the Winter Cherry shopping mall in the city of Kemerovo, and rapidly assumed measures. Measures of investigation are proposed to be added with the consideration of rightful premisses that caused the tragedy and, of course, to propose options for improving governance.

It was noted that the state of shock of people did not immediately allow to pay attention to the rightful premisses that determined the inaction of officials of bodies of government that were obliged in accordance with the current legislation to "prevent" such offenses in the Russian Federation.

The analysis of measures of "subjects of offenses prevention" in the Russian Federation is given. It is shown that the power structure, which is " the right, power and will on something, discretion, commanding," because of the lack of feedback in principle can not be guaranteed against gross errors, the number of which in this situation can be reduced only due to the genius of the governor. The reason for this can be called the delegation of functions and the lack of control over their implementation in social institutions, beginning with the Presidential Administration of the Russian Federation, which, "assisting", i.e., "helping ... in any case" to the President of the Russian Federation, under quite legal foundation if desired can solve the problems of citizens who applied themselves. This can be justified by the combination of the functions of the "authority" and "legal entity" engaged in profittaking, which causes "the permissiveness of the social institution, its officials and the destruction of the individual" in the power structures.

It is suggested taking into account the real constantly changing social environment to move to management based on the principle of feedback. The material basis for the implementation of management based on the principle of "feedback" should be a new concept of ownership as a complex object, including objects and subjects of ownership, the relationship of property subjects to property objects, as well as the relationship between property subjects over the formation, accumulation, alienation (seizure), appropriation, exchange, protection, defense (protection), distribution and redistribution of property objects and other relations. Since the owner refers to the property objects as his own, as to their own, and accordingly - a non-proprietor refers to them as a stranger who does not belong to them, then to eliminate such a legal conflict, it was suggested, having retained private property, to move within part 1 of Art. 244 of the Civil Code of the Russian Federation, to public property, within the framework of which each citizen becomes a co-owner without the allocation of his share. In this case, the governor, with the preservation of all his privileges and using the principle of the division of labor and specialization, acquires the right to use only, that is, to receive, benefit from the property object and manage (dispose), ie create conditions for extracting the most useful properties from the property object in the interests of both society and its enterprising part, but without the right to determine their fate; bear the burden on the contents of the property objects transferred to it, not violate the rights of owners and third parties and be liable for failure to perform duties, improper performance of duties, improper exercise of their rights.
\end{abstract}

Keywords: legal preconditions; national tragedy; government; management; prevention; property; private property; public property; immunity; delegation of functions; legalized confusion of functions; permissiveness.

«Нигде в России не было, но вот повторилось».

Черномырдин В. С.

События 25 марта 2018 г. в торгово-развлекательном центре «Зимняя вишня» г. Кемерово были признаны «национальной трагедией». Из средств массовой информации стало известно, что в час «пик», когда на всех этажах здания собралось максимальное количество посетителей, произошло возгорание, начавшееся в игровом зале этого центра. В результате пожара по официальным данным погибло 64 ни в чем не повинных человека, в том числе 41 ребенок ...

Очередная трагедия национального уровня, приведшая к гибели людей и особенно детей, отозвалась болью не только в сердце каждого россиянина, она стала болью населения многих стран, руководители которых искренне выказали свое соболезнование Президенту РФ Путину В. В.
Реакция региональной власти на гибель людей оказалась мгновенной: исполняющий обязанности губернатора Тулеев А. Г. на место трагедии не поехал, чтобы «автомобили его кортежа не мешали работать спасателям», но сразу же пообещал выплатить пострадавшим семьям из казны субъекта федерации за каждого погибшего 1000000 рублей.

Высшее руководство страны прореагировало не менее оперативно. 26-го марта 2018 г. Президент РФ Путин В.В. лично прибыл в г. Кемерово, где выразил соболезнование семьям погибших, посетил в больнице выживших после пожара и провел оперативное совещание на региональном уровне; Следственный комитет РФ сформировал, по словам Президента РФ, следственную группу в составе 100 человек; в результате следственных мероприятий сразу же были задержаны, а затем арестованы 5 подозреваемых по делу о пожаре в торгово-развлекательном центре «Зимняя вишня»; компен- 
сация семьям сгоревших на пожаре людей была увеличена до 5000000 руб.: 1000000 из федерального бюджета, 1000000 руб. из бюджета Кемеровской области и 3000000 руб. из кармана собственника торгово-развлекательного центра; дано указание провести проверку во всех торгово-развлекательных центрах страны; 28 марта было объявлено днем всероссийского траура ...

Федеральный канал центрального телевидения показал, как Президент РФ Путин В. В. лично дает указание Председателю Следственного комитета РФ, другим высшим руководителям детально разобраться во всех причинах произошедшей трагедии. После такой установки ни у кого в стране не осталось даже малейших сомнений в том, что на месте происшествия будут выявлено всё, что в очередной раз привело к гибели такого количества детей и взрослых, а допустившие оплошность арестованные лица понесут заслуженное наказание ...

Не трудно заметить, что все так оперативно осуществленные действия, по своей сути, очень напоминают известную русскую пословицу: «Пока гром не грянет - поп не перекрестится», но прогресс явно наметился: бесценная жизнь погибшего человека достигла вершины и стала стоить в условиях инфляции 5000000 руб. По этой причине имеет смысл не только ждать результатов работы 100 следователей по установлению доказательств вины арестованных и иных пока еще не привлеченных сотрудников торгово-развлекательного центра «Зимняя вишня», но обратить также внимание на те правовые предпосылки, которые привели к произошедшей национальной трагедии в г. Кемерово и, естественно, предложить варианты совершенствования структуры правления [14, С. 83-98]. Понятно, что такие предложения никоим образом не могут и не должны задеть авторитета должностных лиц разных уровней власти, ибо они, не интересуясь за занятостью новым, просто используют доставшееся им в наследство и отработанное представление о содержании правления и его форме - власти. Однако без правового анализа недостатков и формирования предложений по их устранению избежать новых национальных трагедий в принципе нельзя, а тем более сделать «рывок вперед, создать новые рабочие места, улучшить благосостояние людей и т. п.», поскольку для этого нужна соответствующая материальная база, новые методы ее использования и главное - понимание того, где этот «вперед» находится ...

Предложения по совершенствованию структуры правления в России были научно обоснованы в рамках диссертации на соискание ученой степени доктора философских наук на тему: «Философия теории управления социально-экономической сферой в «мире изменений» XXI века» [15], выполненной на кафедре «Национальная безопасность» тогда еще Федерального государственного бюджетного образовательного учреждения высшего профессионального образования (ФГБОУ ВПО) «Санкт-Петербургский государственный политехнический университет». Диссертация успешно прошла защиту в ФГБОУ ВПО «Балтийский государственный технический университет «ВОЕНМЕХ» им. Д. Ф. Устинова» еще 28 февраля 2014 г., но эксперты Высшей аттестационной комиссии (ВАК) при Министерстве образования и науки (Минобрнауки) в нарушение ч. 1 ст. 19 Конституции РФ почему-то «оценили» ее не по установленным п.п. 9, 10, 11, 12, 13, 14 «Положения о присуждении ученых степеней» (Положение-1), утвержденного постановлением Правительства РФ от 24.09. 2013 г. N 842, критериям, а по надуманными «формальным признакам», так что вопрос о выдаче диплома доктора философских наук до сих пор является открытым ...

Итак, получив персональное указание от Президента РФ, который в соответствии с п. 3 ст. 1 Федерального закона РФ от 28.12.2010 N 403-Ф3 «О Следственном комитете РФ» (Закон-1) сам лично «осуществляет руководство («руководство» - это «направляющая деятельность руководителя, стоящего во главе чего-нибудь» $[26, \mathrm{C}$. 554]) деятельностью Следственного комитета», Председатель Следственного комитета немедленно приступил к исполнению «основной задачи» по «организации и осуществлению в пределах своих полномочий выявления обстоятельств, способствующих совершению преступлений, принятию мер по устранению таких обстоятельств», определенной п.п. 4) п. 4 ст. 1 Закона-1. Высочайшая квалификации 100 следователей гарантировано должна была обеспечить «оперативное и качественное расследование преступлений в соответствии с подследственностью, установленной уголовно-процессуальным законодательством РФ», которое 
также входит в число задач, определенных в п.п. 1) п. 4 ст. 1 Закона-1, что без особого труда сразу же и позволило привлечь к ответственности сотрудников торгово-развлекательного центра «Зимняя вишня» за неисполнение ими своих обязанностей, за ненадлежащее исполнение ими своих обязанностей и ненадлежащую реализацию ими своих прав [12, С. 132] ...

Шоковое состояния выживших в пожаре, неописуемое горе семей сгоревших людей, соучастие в их горе населения г. Кемерово и всей страны, а также фактически мгновенное выявление следователями непосредственных виновников на местном уровне как будто затуманило сознание людей и не позволило в этот период обратить внимание на правовые предпосылки, определившие бездействие должностных лиц властных структур, которые обязаны в соответствии с действующим законодательством осуществлять «профилактику» такого рода правонарушений в РФ.

Применительно, например, к медицине раннему обнаружению, диагностике заболеваний и их профилактике в нашей стране уделяется очень большое внимание, поскольку это позволяет, в частности, в настоящее время существенно снизить расходы на последующее, как правило, не более 2-х недель вне зависимости от состояния больного его лечение в стационаре. Однако положительный опыт Министерства здравоохранения (Минздрава) оказался в РФ не востребованным, хотя еще в 2016 г. Государственной Думой (ГД) РФ был принят Федеральный закон РФ от 23.06.2016 N 182-Ф3 «Об основах системы профилактики правонарушений в Российской Федерации» (Закон-2), который на законодательном уровне в полной мере закрыл «правовую неопределенность» по осуществлению профилактики правонарушений, имевшую место в Законе-1.

В соответствии со ст. 5 Закона-2 «субъектами профилактики правонарушений» в РФ названы:

«1) федеральные органы исполнительной власти;

2) органы прокуратуры РФ;

3) следственные органы Следственного комитета РФ;

4) органы государственной власти субъектов РФ;

5) органы местного самоуправления».

В связи с этим с точки зрения здравого смысла не вызывает никаких сомнений то, что Следствен- ный комитет РФ как «субъект профилактики правонарушений» вполне способен «выявить обстоятельства, способствующие совершению преступлений» и «принять меры по устранению таких обстоятельств» в деятельности федеральных органов исполнительной власти, дислоцированных в Москве, а также органа государственной власти субъекта РФ и органа местного самоуправления, расположенных в г. Кемерово. Более сложной оказывается проблема, связанная с тем, кто и как будет «выявлять обстоятельства, способствующие совершению преступлений» и «принимать меры по устранению таких обстоятельств» в деятельности органов прокуратуры РФ и самих следственных органов Следственного комитета РФ.

Так, в соответствии с ч. 1 ст. 9 Закона-2 «органы прокуратуры РФ осуществляют профилактику правонарушений, обеспечивая надзор за исполнением законов федеральными органами исполнительной власти, Следственным комитетом РФ, органами государственной власти субъектов РФ, органами местного самоуправления и их должностными лицами в соответствии с Федеральным законом РФ от 17.01.1992 N 2202-1 «О Прокуратуре Российской Федерации» (Закон-3), а потому по этому основанию не могут предъявить претензии к самим себе при осуществлении профилактики правонарушений в пределах своей компетенции.

В свою очередь сам Следственный комитет РФ и его следственные органы, решая определенную п.п. 4) п. 4 ст. 1 Закона-1 «основную задачу» по «организации и осуществлению в пределах своих полномочий выявления обстоятельств, способствующих совершению преступлений, принятию мер по устранению таких обстоятельств», вряд ли смогут даже инициативно предъявить претензии к органам прокуратуры РФ в вопросе осуществления профилактики правонарушений в пределах уже своей компетенции. «Дискуссии о соотношении процессуальной самостоятельности следователя, предварительного следствия и прокурорского надзора продолжаются с 2007 г., однако достичь согласия по этим вопросам до сих пор так и не удалось» [1]. В то же время Следственный комитет РФ и его следственные органы вполне могут самокритично оценить свои действия «при осуществлении профилактики правонарушений», связанной с пожарами в торгово-развлекательных центрах, которую 
они, как видно, не проводили вообще, поскольку своевременная реализация такой профилактики без проблем могла бы предотвратить национальную трагедию в г. Кемерово. Здесь совершенно очевидным является то, что ответственность должностных лиц Следственного комитета РФ за неисполнение ими своих обязанностей по профилактике правонарушений, в том числе и в торгово-развлекательном центре «Зимняя вишня» г. Кемерово, ненадлежащее исполнение ими своих обязанностей и ненадлежащая реализация ими своих прав $[12$, С. 132, 134] по рассматриваемым действиям и бездействию вполне соизмерима с аналогичной ответственностью арестованных по делу о пожаре в торговом центре «Зимняя вишня» ...

Осуществляющий на основании п. 3 ст. 1 Закона-1 непосредственное «руководство деятельностью Следственного комитета» Президент РФ в соответствии с ч. 1 ст. 80 Конституции РФ является «главой государства» и реализует на основании ч. 1 ст. 11 Конституции РФ всю «государственную власть в РФ», где власть рассматривается как «право, сила и воля над чем-либо, свобода действий и распоряжений, начальствование» [6, С. 226]. Она используется только и только применительно к социуму для обеспечения жизнедеятельности общества через обогащение его предприимчивой части в предположении, что как только она обогатится, то сразу же наступить всеобщее благоденствие, сохраняя тем самым стабильность такого бытия и исходя из весьма гомоморфного предположения о наличии такой стабильности. Это делает закон изменения состояния объекта правления во времени заранее известным, а потому необходимость в обратной связи, характерной для управления, здесь полностью исключается, что зачастую может привести и приводит к весьма грубым ошибкам, число которых может быть уменьшено только за счет гениальности правителя.

Если применительно к любому гражданину РФ действует определенный ч. 1 ст. 5 «Уголовного кодекса Российской Федерации» от 13.06.1996 N 63-Ф3 (ред. от 07.06.2017) принцип вины, в соответствии с которым «лицо подлежит уголовной ответственности только за те общественно опасные действия (бездействие) и наступившие общественно опасные последствия, в отноше- нии которых установлена его вина», то введенная ст. 91 Конституции РФ «неприкосновенность» Президента РФ, означающая, что он «защищен от всякого посягательства со стороны кого-нибудь» [26, С. 338] и «не подлежит суду» [7, С. 441] справедливо и по законным основаниям исключает любую его ответственность за изданные и неизданные на основании ч. 1 ст. 90 Конституции РФ «указы и распоряжения», которые «обязательны для исполнения на всей территории РФ», в том числе и за "руководство деятельностью Следственного комитета» и проведение «профилактики правонарушений». В этой ситуации совершенно понятными являются утверждения о персонификации такого правления, о его насильственном характере, о таких его исторических стадиях, как интердикция (подавление, запрещение); инфлюация (влияние), в первую очередь в виде суггестии, т. е. внушения, рациональное регулирование совместных действий, совместного труда людей и т. п. [16, С. 6]. Поэтому вполне оправданным следует считать и проводимое в стране воспроизводство именно такой власти на государственном уровне, которое вылилось в выявление и подготовку будущих «лидеров» государства и его коммерческих структур без изменения сущности, содержания и формы правления ...

В рамках рассматриваемой проблемы «профилактики правонарушений» можно упомянуть еще и о неприкосновенности федеральных органов исполнительной власти. О ней говорится в п. 9 РАЗДЕЛА ВТОРОГО «Заключительные и переходные положения» Конституции РФ, при этом, видимо, только Президент РФ, не снимая с этих лиц неприкосновенности, может привлекать их к «ответственности за действия (или бездействие), связанные с выполнением служебных обязанностей» ...

Находясь во главе государства, которое как «специальная организованность» общества, по мнению Аристотеля ( 322 гг. до н.э.), во все времена реализует только три основные функции [17, С. 182]:

1) обеспечивает возможность для предприимчивой части общества получать прибыль (наживу) за счет большинства населения;

2) поддерживает жизнедеятельность большинства с учетом его менталитета на уровне, достаточном для извлечения из него прибыли; 
3) стабилизирует такую ситуацию

в предположении, что после завершения обогащения предприимчивой части общества сразу же наступит и всеобщее благоденствие, Президент РФ исполняет архисложные и весьма многочисленные обязанности, предусмотренные ст. 83; 84; 86-90 Конституции РФ. Кроме того, в соответствии, например, с Главой V Федерального конституционного закона от 17.12.1997 N 2-ФКЗ «О Правительстве Российской Федерации» (Закон- 4) Президент РФ:

- «обеспечивает, т. е. «снабжает чем-нибудь в нужном количестве; делает вполне возможным, действительным, несомненным» [26, С. 350] согласованное функционирование и взаимодействие Правительства РФ и других органов государственной власти;

- руководит деятельностью федеральных органов исполнительной власти, ведающих вопросами обороны, безопасности, внутренних дел, юстиции, иностранных дел, предотвращения чрезвычайных ситуаций и ликвидации последствий стихийных бедствий, деятельности войск национальной гвардии РФ, утверждает по представлению Председателя Правительства РФ положения о них и назначает руководителей и заместителей руководителей этих органов, а также осуществляет иные полномочия как Верховный Главнокомандующий Вооруженными Силами (ВС) РФ и Председатель Совета Безопасности РФ;

- руководит непосредственно и через федеральных министров деятельностью федеральных органов исполнительной власти, указанных выше и находящихся в ведении соответствующих федеральных министерств;

- распределяет функции между указанными выше федеральными органами исполнительной власти и т. п.

Такое обилие весьма емких функций Президента РФ является чрезмерным и, естественно, требует огромных умственных, физических и материальных затрат, тем более что обычный человек может реализовывать множество функций только последовательно ...

Исключением из этого правила следует признать внука выдающегося государственного дея- теля советского периода Молотова В. М., поскольку всеми признано, что «природа отдыхает только на детях великих людей». Общеизвестно, что Никонов В. А. одновременно является Членом Высшего совета партии «Единая Россия», депутатом ГД РФ от «Единой России», Председателем Комитета ГД РФ по образованию и науке, деканом факультета государственного управления ФГБОУ ВО «Московский государственный университет (МГУ) им. М. В. Ломоносова» и постоянным участником политических передач на центральных каналах телевидения [10]. Если заседать в Высшем совете партии «Единая Россия» и участвовать в политических передачах на центральных каналах телевидения можно в свободное от основной работы время, то остается загадкой, как можно совмещать обязанности Председателя Комитета ГД РФ по образованию и науке и декана факультета государственного управления ФГБОУ ВО «МГУ им. М. В. Ломоносова», которые требуют одновременно обязательного присутствия в рабочее время на обоих рабочих местах? Можно предположить, что такая многогранность приводит к тому, что по законным основаниям должностные функции за Никонова В. А. в разных учреждениях выполняют за соответствующее вознаграждение из бюджета другие должностные лица, что, естественно, приводит к раздуванию соответствующих аппаратов и появлению уникального явления под названием «делегирование своих функций» ...

В отличие от Председателя Комитета ГД РФ по образованию и науке и одновременно декана факультета государственного управления ФГБОУ ВО «МГУ им. М. В. Ломоносова» Никонова В. А. очевидная исключительная занятость Президента РФ, предопределила для него по этому основанию необходимость делегировать целый ряд своих полномочий Администрации Президента РФ, «сформированной в соответствии с п. «и» ст. 83 Конституции РФ и финансируемой из средств федерального бюджета [24]. Действительно, в соответствии с п. 1 «Положения об Администрации Президента РФ» (Положение-2), утвержденного Указом Президента РФ от 6 апреля 2004 г. N 490 (Указ-1), Администрация Президента РФ «обеспечивает деятельность Президента РФ и осуществляет контроль за исполнением решений Президента РФ», который, естественно, по этому 
основанию все-таки должен принимать их сам.

Наличие более 2000 должностных лиц в Администрации Президента РФ, по словам самого Президента РФ, в принципе делает невозможным для него при такой нагрузке осуществлять еще и «контроль» за их работой, что является характерным для используемого метода «править».

Отсутствие «контроля» со стороны Президента РФ за работой должностных лиц своей Администрации, прежде всего, проявляется в вопросе о компетентности ее должностных лиц. Уникальным примером стала оценка самого Президентом РФ работы заместителя Руководителя Администрации Президента РФ - пресс-секретаря Президента РФ Пескова Д. С., который в соответствии с абзацем 3 п. 7 Положения-2 «непосредственно подчиняется» Президенту РФ и о котором Президент РФ в отснятом о его персоне кинофильме прямо сказал, что «тот несет иногда такую пургу», что за голову можно схватиться ... Здесь имеют место простой вопрос: почему при такой оценке Президента РФ заместитель Руководителя Администрации Президента РФ - пресс-секретарь Президента РФ Песков Д. С. не освобожден Президентом РФ в соответствии с абзацем 6 п. 7 Положения-2 от занимаемой должность?

Другим негативным результатом отсутствия такого «контроля» могут служить юридические факты прямого нарушения Федерального закона РФ от 02.05.2006 N 59-Ф3 (ред. от 02.07.2013) «О порядке рассмотрения обращений граждан РФ» (Закон-5) должностными лицами Администрации Президента РФ (консультантом А. Модзелевской, советниками С. Фатуевым и М. Дремановым, главным советником К. Харитоненко), когда они:

- незаконно применяют ч. 3 ст. 8 Закона-5, которая не может использоваться в случаях, когда обращения по обжалованию юридически значимых действий должностных лиц уже не один раз прошли все возможные и мыслимые в РФ инстанции;

- полностью игнорируют применение ч. 6 ст. 8 Закона-5, которая гласит: «Запрещается направлять жалобу на рассмотрение в государственный орган ... или должностному лицу, решение или действие (бездействие) которых обжалуется»;

- не исполняют п. 1) ч. 1 ст. 10 Закона-5, кото- рый гласит: «Должностное лицо обеспечивает объективное, всестороннее и своевременное рассмотрение обращения, в случае необходимости - с участием гражданина, направившего обращение», и, по сути, вообще не дают ответа по существу поставленных вопросов;

- незаконно применяют при наличии полного объема сведений о принятых с нарушением требований нормативных документов мерах по рассмотрению поставленного в обращении вопроса уникальную формулировку: «В связи с тем, что в Вашем заявлении отсутствуют сведения о рассмотрении поставленного в обращении вопроса должностными лицами, в компетенцию которых входит его решение, для обеспечения получения Вами ответа по существу поставленного вопроса Ваше обращение направляется тем же должностным лицам».

Действительно, в соответствии с п. 4 Положения-2 должностные лица Администрации Президента РФ в основном «содействуют», т. е. «соучаствуют, помогают ... в каком-либо деле», Президенту РФ в решении вопросов, которые он из-за своей занятости им делегировал. Однако, «содействуя» Президенту РФ «в решении вопросов, касающихся обеспечения прав и свобод человека и гражданина», который, как отсюда следует, и здесь «решение» должен принимать все-таки сам, должностные лица Администрации Президента РФ жалобы граждан до Президента РФ просто не допускают, хотя ст. 2 Конституции РФ и гласит: «Человек, его права и свободы являются высшей ценностью. Признание, соблюдение и защита прав и свобод человека и гражданина - обязанность государства», при этом ч. 2 ст. 80 Конституции РФ утверждает: «Президент РФ является гарантом Конституции РФ, прав и свобод человека и гражданина», а приведенная в ч. 1 ст. 82 клятва Президента РФ гласит: «Клянусь при осуществлении полномочий Президента РФ уважать и охранять права свободы человека и гражданина, соблюдать и защищать Конституцию РФ ...».

Реализуя такое странное «содействие» Президенту РФ в решении указанных вопросов по обеспечению прав и свобод человека и гражданина, Администрация Президента РФ в то же время, в соответствии с Указом Президента РФ от 17 фев- 
раля 2010 г. N 201 (Указ-2) имеет «одной из основных функций своих работников своевременное рассмотрение обращений российских граждан», при этом, как было отмечено, Администрация Президента РФ должна «обеспечивать объективное, всестороннее и своевременное рассмотрение обращения, в случае необходимости - с участием гражданина, направившего обращение».

Здесь словосочетание «рассмотреть обращение» означает только одно: «принять меры, направленные на восстановление или защиту нарушенных прав, свобод и законных интересов гражданина», т. е. выполнить все действия, предусмотренные п. 1) - 5) ч. 1 ст. 10 Закона-5, а, по сути, разрешить по законным основаниям возникшую проблему, а не пересылать прошедшие все возможные в РФ инстанции Обращения на рассмотрение должностных лиц, которые приняли незаконное решение и чьи действия (бездействие) обжалуются ...

В то же время в рамках ч. 1 ст. 45 Конституции РФ финансируемая из федерального бюджета Администрация Президента РФ, «содействуя» Президенту РФ, при наличии желания и без всякого напряжения вполне самостоятельно может разрешить за Президента РФ любую проблему обратившегося гражданина. Поскольку Президент РФ делегировал Администрация Президента РФ функцию «принимать меры, направленные на восстановление или защиту нарушенных прав, свобод и законных интересов гражданина», а в соответствии с абзацами 9 и 20 п. 5 Положения-2 «администрация в целях обеспечения деятельности Президента РФ осуществляет:

- ... контроль за исполнением федеральных законов (в части, касающейся полномочий Президента РФ, в том числе по обеспечению прав и свобод человека и гражданина)»;

- ... учет и анализ обращений граждан,..., представление соответствующих докладов Президенту РФ»,

то совершенно естественным для нее является в рамках категории «действовать» потребовать от нарушивших действующее законодательство должностных лиц исполнительной и законодательной власти в порядке указанного «контроля» просто в полном объеме «соблюдать, исполнять и применять» Конституцию РФ и соответствующие нормативные документы.
Отсутствие контроля со стороны Президента РФ за результатами работы 2000 сотрудников Администрации делает вполне понятным весьма затруднительное для них исполнение своих обязанностей, изложенных в абзацах 9 и 20 п. 5 Положения-2. Однако эти бесконтрольные «затруднения» в реализации Обращений граждан все-таки можно оправдать сложностями созданной в организационной структуре правления - власти правовой ситуации. Действительно, с одной стороны, «Администрация Президента РФ является государственным органом» (п. 1 Положение-2), а, значит, вроде бы обязана доводить Обращения до главы государства, осуществляющего государственную власть в РФ, однако, с другой стороны, «Администрация Президента РФ является юридическим лицом» (п. 17 Положения-2), которое «преследует извлечение прибыли в качестве основной цели своей деятельности (коммерческие организации)», либо извлечение прибыли все равно имеет место быть, но оно уже не является основной целью и не распределяет полученную прибыль между участниками (некоммерческие организации)» (ч. 1 ст. 50 Гражданского кодекса (ГК) РФ), а потому, видимо, активно занимаясь извлечением прибыли, и за не имением времени Администрация Президента РФ не только не разрешает Обращения граждан сама, но не считает даже нужным по этому основанию доводить Обращения до Президента РФ, физически не имеющего возможности вообще контролировать работу этих 2000 сотрудников, которым он делегировал свои полномочия.

Аналогичная ситуация по срастанию в единое целое государственных органов и юридических лиц имеет место:

1) в прокуратуре РФ, которая в соответствии с ч. 1 ст. 11 Закона-3 включает в себя «Генеральную прокуратуру РФ, прокуратуры субъектов РФ, приравненные к ним военные и другие специализированные прокуратуры, научные и образовательные организации, редакции печатных изданий, являющиеся юридическими лицами, а также прокуратуры городов и районов, другие территориальные, военные и иные специализированные прокуратуры»;

2) Следственном комитете РФ, где в соответствии с. ч. 3 ст. 5 Закона-1 «Следственный комитет, Главное военное следственное управление, главные следственные управления и следственные управ- 
ления Следственного комитета по субъектам РФ (в том числе подразделения указанных управлений по административным округам) и приравненные к ним специализированные (в том числе военные) следственные управления и следственные отделы Следственного комитета и учреждения Следственного комитета являются юридическими лицами»;

3) органах государственной власти субъектов РФ, где в соответствии с. ч. 7 ст. 4 Федерального закона от 6.10.1999 N 184-Ф3 «Об общих принципах организации законодательных (представительных) и исполнительных органов государственной власти субъектов Российской Федерации» (Закона-6) «законодательный (представительный) орган государственной власти субъекта РФ обладает правами юридического лица», а в соответствии с ч. 4. ст. 20 Закона-6 «высший исполнительный орган государственной власти субъекта РФ обладает правами юридического лица»;

4) органах местного самоуправления», где в соответствии с. ч. 2 ст. 41 Федерального закона от 6.10.2003 N 131-Ф3 «Об общих принципах организации местного самоуправления в Российской Федерации» (Закона-7) «органы местного самоуправления ... наделяются правами юридического лица»;

5) федеральных органах исполнительной власти, где, с одной стороны, в соответствии с абзацем 1 ст. 1 Закона-4 «Правительство РФ является органом государственной власти РФ», а, с другой стороны, в соответствии с п. г) ч. 1 ст. $114 \mathrm{KoH}-$ ституции РФ» «осуществляют управление федеральной собственностью», при этом на основании Указа Президента РФ от 28 октября 1994 г. N 2027 «О полномочиях Правительства Российской Федерации по осуществлению передачи объектов права федеральной собственности в государственную собственность субъектов Российской Федерации и муниципальную собственность» (Указ-3) наиболее широкими полномочиями наделяется Правительство РФ по «управлению и распоряжению» (в общепринятом понимании являющихся синонимами $[9$, С. 313; 8, С. 501]) объектами федеральной собственности, в рамках которых, однако, «распоряжение» позволяет изменять их юридическую судьбу [20, комментарий к ст. 209].

Правительству РФ в этих условиях, в частности, предоставлено право делегировать свои полномочия по такому «управлению и распоряжению» объ- ектами федеральной собственности федеральным органам исполнительной власти в соответствии с нормативно-правовыми актами РФ, а именно:

- Министерству экономического развития РФ (Минэкономразвитие России);

- Министерству обороны РФ;

- Российской границе (Росгранице);

- Минобрнауки;

- Министерству атомной энергетики РФ;

- Министерству транспорта РФ;

- Министерству природных ресурсов и экологии РФ;

- Российской академии наук и т. п.

В результате такого делегирования Правительством РФ Минэкономразвитие России принимает на себя функции по выработке государственной политики и нормативно-правовому регулированию в сфере анализа и прогнозирования социальноэкономического развития, развития предпринимательской деятельности, в том числе среднего и малого бизнеса, внешнеэкономической деятельности (за исключением внешней торговли), имущественных отношений, несостоятельности (банкротства) и финансового оздоровления, оценочной деятельности, земельных отношений (за исключением земель сельскохозяйственного назначения), государственного кадастра недвижимости, осуществления государственного кадастрового учета и кадастровой деятельности, государственной кадастровой оценки земель, государственного мониторинга земель (за исключением земель сельскохозяйственного назначения), государственной регистрации прав на недвижимое имущество, геодезии и картографии, государственной статистической деятельности, инвестиционной деятельности и государственных инвестиций, формирования межгосударственных и федеральных целевых программ (долгосрочных целевых программ), ведомственных целевых программ, разработки и реализации программ социально-экономического развития РФ, создания и функционирования особых экономических зон на территории РФ, управления государственным материальным резервом, размещения заказов на поставки товаров, выполнение работ, оказание услуг для государственных и муниципальных нужд.

В свою очередь Минэкономразвитие России делегирует реализацию такой государственной политики и нормативно-правового регулиро- 
вания Федеральному агентству по управлению государственным имуществом (Росимуществу), которое осуществляет функции по указанному выше «управлению и распоряжению» федеральным имуществом, в том числе в области земельных отношений, по оказанию государственных услуг и правоприменительные функции в сфере имущественных отношений.

Росимущество, используя схему поручений, делегирует далее их своим территориальным органам. Например, на территории Ленинградской области таким территориальным органом является Территориальное управление Росимущества в Ленинградской области. В соответствии с «Положением о территориальном управлении федерального агентства по управлению государственным имуществом в Ленинградской области» (Положение-3), утвержденным Приказом Росимущества от 5 марта 2009 г. N 64 (в ред. Приказов Росимущества от 07 авг. 2009 г. N 229; от 29 сент. 2010 г. N 263; от 18 ноябр. 2010 г. N 332) оно осуществляет функции «по управлению федеральным имуществом, по организации продажи приватизируемого федерального имущества, по реализации имущества, арестованного во исполнение судебных решений или актов органов, которым предоставлено право принимать решения об обращении взыскания на имущество, а также по реализации конфискованного, движимого бесхозяйного, изъятого и иного имущества, обращенного в собственность государства в соответствии с законодательством РФ, по оказанию государственных услуг и правоприменительные функции в сфере имущественных и земельных отношений». Указанное Территориальное управление осуществляет свою деятельность во взаимодействии с Территориальными органами федеральных органов исполнительной власти, с органами исполнительной власти субъектов РФ, органами местного самоуправления, и полномочными представителями Президента РФ в федеральных округах.

Все перечисленные органы государственной власти от имени РФ осуществляют права собственника, т. е. по сути юридического лица, в определенном законодательством объеме.

Кроме того, органы исполнительной власти РФ, к числу которых были отнесены отдельные министерства, например, Министерство РФ по делам гражданской обороны, чрезвычайным ситуациям и ликвидации последствий стихийных бедствий (МЧС), в соответствии с п. 18 «Положения о Министерстве Российской Федерации по делам гражданской обороны, чрезвычайным ситуациям и ликвидации последствий стихийных бедствий» (Положение-4), утвержденного Указом Президента РФ от 11 июля 2004 г. N 868 (Указ-4) прямо обозначено как юридическое лицо, другие министерства определялись как учреждения и наделялись правами юридического лица [20, п. 7 комментария к ст. 125]. Аналогичная тенденция имела место в отношении ведомств и т. п.

Такое специфическое приобщение к субъектам частного права органов государственной власти и органов местного самоуправления сказалось и на таком социальном институте РФ как, например, ее ВС [12, С. 186 - 187].Так, в соответствии со своим конституционным назначением [21, ч. 1 ст. 59; п. м) ст. 71; п. д) ст. 114)] ВС РФ должны реализовывать только защиту Отечества, а потому на основании п. 1 ст. 10 Федерального закона от 31.05.96 г. N 61-Ф3 «Об обороне» (Закон-8) они определялись как «государственная военная организация». ВС РФ имеют в соответствии с п. 12 ст. 1 того же Закона-8 имущество, являющееся федеральной собственностью, что однозначно превращает их в несобственника, и, по мнению известного правоведа, цивилиста профессора О. Н. Садикова, обязывает их реализовывать свои имущественные отношения с собственником - РФ как основанные на административном или ином властном подчинении одной стороны другой. В то же время, с другой стороны, в соответствии с п. 12 ст. 1 Федерального закона от 31.05.1996 N 61-Ф3 (ред. от 09.11.2009 г.) «Об обороне» имущество ВС РФ может находиться у них только на правах хозяйственного ведения или оперативного управления, которые составляют основной массив отношений, регулируемых гражданским законодательством. По этой причине бытующее в ВС РФ гражданско-правовое представление собственности заставляло и заставляет разрабатывать самые различные экономико-правовые схемы, обходящие эту правовую коллизию.

Так, например, до апреля 2009 г. в ВС РФ субъектами имущественных правоотношений выступали органы военного управления или специально создаваемые организации (учреждения, федеральные государственные унитарные предприятия (ФГУПы)), наделенные правами юридического лица 
в соответствии с утвержденными установленным порядком положениями о них, что, по сути, открывало для ВС РФ возможность заниматься извлечением прибыли, но не самостоятельно, а через эти органы военного управления и созданные организации, которые полностью компенсировали запрет на предпринимательскую деятельность ВС РФ, открывая тем самым широкие возможности для коррупции, казнокрадства и взяточничества.

С апреля 2009 г. новой экономико-правовой схемой стало создание в ВС РФ управлений объединений, соединений и воинских частей в форме федерального бюджетного учреждения (ФБУ), которые в соответствии с п. 1 ст. 11.1 Федерального закона от 31.05.1996 N 61-Ф3 (ред. от 09.11.2009 г.) «Об обороне» прямо определяются «в качестве юридических лиц». Отсюда следует, что хотя ВС РФ заниматься самостоятельно извлечением прибыли вроде бы и нельзя, поскольку они не являются юридическим лицом, но зато могут специально создавать коммерческие организации, которые успешно обходят этот запрет. Именно по этой причине основное внимание в военном праве, обслуживающем имущественные отношения в ВС РФ, и уделяется научным исследованиям, обеспечивающим эффективную организацию не защиты Отечества, а именно правовому обеспечению хозяйственного оборота в них с целью извлечения прибыли [3-5; 19; 22; 23; 25; 31-35].

Указанная ситуация была глубоко исследована заведующим кафедрой коммерческого права ФГБОУ ВО «Санкт-Петербургский государственный университет» профессором Попондопуло В. Ф. Он писал, что такое «узаконенное смешение, с одной стороны, принципов основной, функциональной, характерной для «государственного органа», а с другой стороны, свободной деятельности его как «юридического лица», распространение принципа первого типа деятельности на второй, и наоборот, является недопустимым, потому что ведет к вседозволенности социального института, его должностных лиц и уничтожению индивида» [30, С. 12]. Именно такое «узаконенное смешение» и создает материальноправовые основы для коррупции, казнокрадства, взяточничества и даже терроризма в РФ.

Эта вседозволенность усугубляется еще и дополнительным «перекладыванием» должностными лицами Администрации Президента РФ своих обязанностей на заявителя, которому они предлагают в этой ситуации «подавать в суд на высокопоставленных лиц», обладающих неприкосновенностью, хотя решение по Обращению не выходит за рамки исполнения должностными лицами Администрации своих обязанностей.

Отсюда следует, что в силу чрезвычайной загрузки высших руководителей страны принятое делегирование ими своих функций множеству финансируемых из бюджета должностных лиц без контроля за исполнением ими своих обязанностей, а также узаконенное смешение функций государственных органов и юридических лиц являются теми правовыми предпосылками, которые и могут привести, в частности, к национальным трагедиям.

Становится понятно, что используемое в РФ понимание категории «правление» требует своего совершенствования.

Прежде всего, надо обратиться внимание на то, что реальная среда обитания людей является не стабильной, а постоянно меняющейся, представляющей собой «любые компоненты, неподконтрольные субъектам, которые, однако, способны к активному воздействию на нее, на общественные процессы в ней» [13, С. 5]. Использование применительно к такой реальной постоянно меняющейся социальной среде при весьма гомоморфном предположении о ее стабильности категории «править» является грубым допущением. Так, по В. И. Далю понятие «править» означает «исполнять или совершать, соблюдая должное» [8, С. 307], т. е. не выходить за рамки того, что уже было, сохраняя тем самым стабильность существования людей. Само же правление неизменно исходит, как было отмечено выше, из предполагаемого априорного факта о наличии такой стабильности, означавшей, что закон изменения состояния объекта правления во времени заранее известен, т. е. стабилен, а потому необходимость в обратной связи, составляющей основу, существо управления, здесь полностью исключается. В то же время «обеспечение постоянства» некоторой величины, некоторого процесса неизменно связывается с категорией «регулировать», которое при отсутствии обратной связи называется «программным» или «разомкнутым» регулированием [27, С. 19]. Отсюда следует, что метод «править» по содержанию тождественен категории «регулировать», а по форме отображается его организационной структурой, которая и называется «власть». 
Материальной основой реализации такого правления является экономическое по Г. Гегелю представление о собственности как объектах собственности и ее экономико-политическое представление по К. Марксу как отношения собственников к объектам собственности как к своим, как к принадлежащим им, и соответственно - несобственников к ним как к чужим, не принадлежащим им.

В рамках юридического представления собственности указанные варианты экономического и экономико-политического представления собственности были закреплены специально разработанным для этого соответствующим «правом собственности» только в виде правомочий собственника «владеть, пользоваться и распоряжаться», где правомочие «распоряжаться» сегодня почему-то позволяет менять юридическую судьбу объекта собственности, а отсутствие юридического закрепления прав несобственника предопределяет несоответствие (дефицитарность) экономического, экономико-политического и правового представления собственности [18].

Становится ясно, что если, например, РФ определено собственником выделенных ему законодателем в результате разграничения объектов собственности, то все остальные субъекты собственности (субъекты федерации, муниципальные образования, весь многонациональный народ и каждый гражданин) должны выступать по отношению к такой федеральной собственности только в качестве несобственников. Отсюда следует, что:

- государство, определив себя собственником, должно относиться к объектам собственности как к своим, а все другие, в том числе субъекты РФ, муниципальные образования, сами граждане и юридические лица должны были бы относиться к ним как к чужим, не принадлежащим им;

- субъекты РФ, получившие статус собственника, должны относиться к объектам собственности как к своим, а все другие, в том числе государство, муниципальные образования, сами граждане и юридические лица должны были бы относиться к ним как к чужим, не принадлежащим им;

- муниципальные образования, также превращенные в собственников, должны относиться к объектам собственности как к своим, а все другие, в том числе государство, субъекты федерации, сами граждане и юридические лица должны были бы относиться к ним как к чужим, не принадлежащим им.

Становится ясно, что в таком представлении собственности формы федеральной собственности, собственности субъектов федерации и муниципальной собственности, а также экономические интересы государства, субъектов федерации и муниципальных образований, составляющие, по сути, единое целое в принципе оказываются коллизионными и противопоставленными друг другу, ибо здесь отторгнутые от объектов собственности «наемные работники действительно только могут сами приходить в рабство, сами себя кормить, поить, одевать и сами себя заставлять работать» [17, С. 163]. Проведенный анализ показывает полную несостоятельность применения для реализации рыночного оборота деления права собственности на различные формы, успешно действовавшего для обеспечения оборота при социалистическом способе производства.

Кроме того, по аналогии с социалистическим способом производства понятия федеральной собственности, собственности субъектов федерации и муниципальной собственности законодатель связал соответственно с населением в целом, с населением, проживающим на территории субъекта РФ и проживающим на территории городского или сельского поселения либо иного муниципального образования, интересам которых и которым они должны были служить, неся соответствующую ответственность. Однако с учетом этого если рассматривать, например, собственность субъекта федерации как отношение населения, проживающего на территории этого субъекта федерации, как к своему, а отношение всего остального населения страны к нему как к чужому, то тем самым все это остальное население оказывается лишенным возможности относиться к указанному имуществу как к своему, т. е. также быть его собственником. Поэтому выделение муниципальной собственности как самостоятельной по территориальному признаку и деление государственной собственности на части также по территориальному признаку приводит к глобальному противоречию экономического и экономико-политического представления собственности и его правового представления. Следовательно, 
существующее деление собственности на формы нельзя признать научно обоснованным, а, значит, и правомочным.

Это подтверждается так же и отмеченными еще Аристотелем основными функциями государства: не трудно заметить, что такие формы собственности и экономические интересы таких собственников, направленные по действующему законодательству вроде бы на «обеспечение интересов большого количества людей, проживающих на конкретной территории» [20, п. 3 комментария к ст. 212] оказываются противопоставленными интересам и этих людей, поскольку «трехслойный пирог» из введенных форм собственности создает только видимость трехкратного возникновения права собственности у отдельных групп населения, проживающих на конкретной территории, а на самом деле устраняет это население от объектов собственности и прикрывает факт скрытого присвоения социальными институтами различного уровня фактических прав собственника, создавая на уровне государства благодатную почву для коррупции, взяточничества и казнокрадства, поскольку общество в соответствии со здравым смыслом может только делегировать этим социальным институтам правомочия «пользоваться» и «управлять» (распоряжаться) объектами государственной и муниципальной собственности, но не «владеть» ими. Такое мнение прямо следует из ст. 2 Конституции РФ, в соответствии с которой «народ осуществляет свою власть непосредственно, а также через органы государственной власти и органы местного самоуправления». Однако указанные социальные институты по-прежнему, как и при социализме, продолжают взимать с членов общества, которое по факту является действительным собственником объектов государственной и муниципальной собственности, плату за пользование его же объектами собственности, оставив без внимания тот факт, что ни один собственник не берет с себя плату за пользование своим же объектом собственности [12, С. 205].

В то же время наличие в постсоциалистической России «трехслойного пирога» из «признаваемых и защищаемых равным образом ... государственной и муниципальной форм собственности» [21, п. 2 ст. 8] не предусматривает их равного участия в формировании имущественных отношений в РФ и лежащего в их основе имущественного комплекса, поскольку вся нагрузка ложится на государство, являющееся собственником федеральной собственности, которая активно переводится в частную собственность.

Ориентация не на стабильную, а на меняющуюся среду бытия требует перехода к использованию метода «управлять», сущность которого состоит в выявлении рассогласования между управляющим воздействием и его результатом («принцип обратной связи») и его изменении для достижения поставленной целей и решения сформулированных для этого с учетом конкретной ситуации задач [17, C. 140].

Материальной основой реализации управления на основе принципа «обратной связи» должно стать новое представление о собственности.

Применительно к меняющейся среде бытия ее следует рассматривать как сложный, включающий в себя объекты и субъекты собственности, отношения субъектов собственности к объектам собственности, а также отношения между субъектами собственности по поводу образования, накопления, отчуждения (захвата), присвоения, обмена или мены их, охраны, обороны (защиты), распределения и перераспределения объектов собственности и иных отношений $[17$, С. 12]. Такой подход определяет возможность взаимодействия субъектов и объектов собственности, что придает им эмерджентные свойства, которыми отдельно объекты собственности и субъекты собственности не обладали. В рамках такого структурного представления собственности собственник и несобственник при наличии волеизъявления собственника и согласии несобственника реализуют функцию «управлять» (распоряжаться) именно для извлечения максимально полезных свойств из объектов собственности [11, С. 92 - 96], но без права изменять юридическую судьбу объекта собственности, поскольку в общепринятом понимании только правомочие «владеть» объектом собственности непосредственно связанно с правом определять его юридическую судьбу. Это открывает возможность обеспечить в условиях вариации среды хозяйствования жизнедеятельность общества не только усилиями его предприимчивой части, после обогащения которой должно наступить и всеобщее благоденствии, но и совместными усилиями и общества, и его предприимчивой части. 
Если деятельность предприимчивой части общества обеспечивается частной собственностью, то непосредственное участие общества в создании материальных благ может быть обеспечено с помощью публичной собственности, в рамках которой каждый гражданин становится сособственником достояния страны без выделения его доли. Это нововведение по законным основаниям обеспечивается ч. 1 ст. 244 ГК РФ, которая ввела понятие «общей собственности, круг участников которой законом не ограничен», а потому может быть распространена и на все общество. Кроме того, предоставленная законом возможность самим участникам общей собственности выбирать их форму подтверждают и с этой стороны принципиальную возможность перехода от коллизионного «трехслойного пирога» из форм собственности, обеспечивающих, по сути, интересы и риски только предприимчивой части общества, к публичной собственности, обеспечивающей интересы и общества, и его предприимчивой части [12, С. 206].

Отсюда следует, что отказ в условиях строящегося российского капитализма от необоснованного, неоправданного и противоречивого деления по аналогии с социалистическим способом производства собственности на формы полностью позволит устранить возникшие по этому основанию проблемы, перейдя от форм собственности к публичной собственности, собственником которой будет выступать все российское общество. В этом случае субъектом такой публичной собственности следует признать именно общество в целом и каждого его члена в отдельности как сособственника без выделения его доли.

Поскольку право такой публичной собственности принадлежит всему народу, то по отношению к другим странам оно является односубъектным, и все другие государства как несобственники автоматически обязаны воздерживаться от совершения каких бы то ни было действий, препятствующих собственнику в осуществлении по его усмотрению его права публичной собственности.

Наличие граждан, выступающих в роли сособственников, определяет право их общей совместной собственности, при которой, помимо рассмотренных выше внешних отношений участников такой собственности со всеми другими странами, существуют также внутренние отношения между самими участниками этой публичной собственно- сти, которые направлены на согласование их воли при осуществлении принадлежащих им правомочий по одновременному владению, пользованию и распоряжению общими объектами собственности. В публичной собственности право каждого сособственника не ограничивается какой-то конкретной частью общего имущества, а распространяется на всю землю и все имущество, в том числе и на доходы, которые оно приносит, и падающие на него обременения. Такая совместная публичная собственность может возникнуть независимо от того, относится ли оно к неделимому имуществу, к имуществу, не подлежащему разделу в силу закона, или к делимому. Наиболее характерными признаками, присущими совместной публичной собственности независимо от оснований ее возникновения являются следующие [20, п.п. 1 и 2 Главы 16; ст. 244]:

- она является многосубъектной;

- ее предмет составляет одно и то же имущество, которое относится к общему;

- в общей публичной собственности граждан наряду с внешними отношениями сособственников со всеми третьими странами существуют также и внутренние отношения между самими сособственниками.

Одновременное использование публичной и частной собственности полностью соответствует мнению известного советского правоведа профессора М. М. Агаркова (1890-1947 гг.), который отмечал, что социальный строй, основанный только на частных или только на публичных началах, только на частной собственности или только на государственной (общенародной) собственности не ведет к построению гуманного общества и гарантиям естественной свободы личности. «И в том, и в другом случае благие намерения ведут к уничтожению личности, а без личности нет и не может быть общества» [2, С. 40 - 42], так как без нее невозможны развитие и прогресс.

Естественно, что в этом случае наполнение бюджета РФ может обеспечиваться не только за счет максимально возможной социальной составляющей объектов публичной собственности, но и за счет налогов на объекты частной собственности. Поскольку и объекты публичной собственности, и объекты частной собственности должны обладать равными правами при наполнении бюджета страны, который должен использоваться и в инте- 
ресах всего общества, и его предприимчивой части, то в меняющихся условиях бытия возникает острая необходимость в установлении их оптимального качественно-количественного соотношения.

Введение наряду с частной собственностью публичной собственности, в рамках которой каждый гражданин становится сособственником достояния страны без выделения его доли, предопределяет переход от правления с характерными для него ошибками и промахами, приводящими к национальным трагедиям, к управлению на основе принципа «обратной связи», которое лишено этих недостатков, поскольку позволяет оптимально сочетать частное и публичное. В этом случае правитель с сохранением всех его привилегий и, используя принцип разделения труда и специализации, приобретает право только пользоваться, т. е. получать, извлекать пользу из объекта собственности и управлять (распоряжаться), т. е. создавать условия для извлечения максимально полезных свойств из объекта собственности в интересах и общества, и его предприимчивой части, но без права определять их судьбу; нести оговоренное с собственниками бремя по содержанию переданных ему объектов собственности, не нарушать права собственников и третьих лиц и отвечать за неисполнение обязанностей, за ненадлежащее исполнение обязанностей, за ненадлежащую реализацию своих прав [17, С. 245].

Таким образом, переход от «правления» к «управлению» на основе принципа «обратной связи», материальной основой которого является оптимальное использование публичной собственности, в рамках которой каждый гражданин становится сособственником достояния страны без выделения его доли, и частной собственности, в полной мере устраняет материально-правовые предпосылки национальных трагедий, поскольку делает ответственным за них и частных собственников, и сособственников публичной собственности, и социальные институты, обеспечивающие их совместное функционирование.

\section{Список литературы}

1. Апостолова Н. Н. Прокурорский надзор и предварительное следствие как гарантии обеспечения прав и свобод личности / Российская юстиция. - 2017. - № 3.
2. Агарков М. М. Проблемы злоупотребления правом в советском гражданском праве. // Известия АН СССР. - 1946. - № 6. - С. 40-42.

3. Бараненков В. В. Военная организация как юридическое лицо в системе Федеральной пограничной службы Российской Федерации: Дис. ... канд. юрид. наук. 20.02.03.

4. Бараненков В. В. Теоретико-правовые основы юридической личности военных организаций: Дис. ... д-ра юрид. наук. 20.02.03.

5. Виноградов А. Ю. Гражданская правосубъектность воинской части: Дис. ... канд. юрид. наук. 20.02.03.

6. Даль В. И. Толковый словарь живого великорусского языка. В 4 тт. Т. 1: А - 3. - М.: ОЛМА-ПРЕСС, 2003. - 640 c.

7. Даль В. И. Толковый словарь живого великорусского языка. В 4 тт. Т. 2: И - О. - М.: ОЛMA-ПРЕСС, 2003. - $672 \mathrm{c}$.

8. Даль В. И. Толковый словарь живого великорусского языка. В 4 тт. Т. 3: П - Р. - М.: ОЛMА-ПРЕСС, 2003. - $576 \mathrm{c}$.

9. Даль В. И. Толковый словарь живого великорусского языка. В 4 тт. Т. 4: С - V. - М.: ОЛMА-ПРЕСС, 2003. - $576 \mathrm{c}$.

10. Викепедия.

11. Домаков В. В. Теория права на основе сущностного признака - собственности. - СПб.: Издво «Стратегия будущего», 2014. - 283 с.

12. Домаков В. В. Теория права на основе сущностного признака общественных отношений собственности (на примере Российской Федерации) - СПб.: Изд-во «Стратегия будущего», 2011. $-356 \mathrm{c}$.

13. Домаков В. В. Философские аспекты управления социально-экономической сферой в меняющихся условиях хозяйствования. - СПб.: Изд-во «Стратегия будущего», 2012 - 307 с.

14. Домаков В. В. Философия методов «управлять», «регулировать» и модификации метода «регулировать» - метода «править» / Наука. Промышленность. Образование. Культура. Формирование духовно-нравственного и физического воспитания нации: Материалы X съезда Петровской академии наук и искусств. Секция «Экономика. Управление социально-экономическими системами». - СПб.: Петровская академия наук и искусств, 2017. (29-30 сентября) - 188 с. - С. 83-98. 
15. Домаков В. В. Философия теории управления социально-экономической сферой в «мире изменений» XXI века: Диссерт. ... на соискание ученой степени доктора филос. наук: (09.00.11) / ФГБОУВПО «Санкт-Петербургский государственный политехнический университет». - СПб., 2014. - 348 с.

16. Домаков В. В. Философия управления социально-экономической сферой в условиях изменений бытия XXI века. - СПб.: Изд-во «Стратегия будущего», 2013 - 348 c.

17. Домаков В. В Экономико-хрематистическая теория обеспечения жизнедеятельности общества и его предприимчивой части в моделях социально-экономической сферы / Книга 4. Экономико-хрематистическая доктрина обеспечения жизнедеятельности и общества, и его предприимчивой части в эволюционной модели социально-экономической сферы и ее правовое обеспечение. - СПб.: Изд-во «Стратегия будущего», 2016 г. - 617 c.

18. Домаков В. В., Чернолес В. П. Диплом № 33 - $S$ на открытие «Закономерность изменения эффективности жизнедеятельности общества в условиях вариации среды хозяйствования» от 23. 11. 2007 г., г. Москва. Регистрационный № 445;

19. Зыкова И. В. Особенности правового регулирования отношений по созданию военных организаций как юридических лиц: Дис. ... канд. юрид. наук. 20.02.03.

20. Комментарий к Гражданскому кодексу Российской Федерации, части первой (постатейный); рук. автор. кол-ва и отв. ред. д-р юрид. наук, проф. О. Н. Садиков. - М.: Юридическая фирма КОНТРАКТ; ИНФРА-М, 1997. - ХХП. - 778 с. - комментарий к ст. 209.

21. Конституция Российской Федерации. - ч. 1 ст. 59; п. м) ст. 71; п. д) ст. 114).

22. Лесовой В. В. Правовой режим имущества военных организаций: Дис. ... канд. юрид. наук. 20.02.03.

23. Манов В. В. Воинская часть Вооруженных Сил Российской Федерации как участник гражданских правоотношений: Дис. ... канд. юрид. наук. 20.02.03

24. Мелехин А. В. Административное право Российской Федерации: Курс лекций / Подготовлен для системы Консультант Плюс, 2009.

25. Нагорныцй И. А. Воинская часть как субъект советского права: Дис. ... канд. юрид. наук. 20.02.03.
26. Ожегов С. И. Толковый словарь русского языка: Около 100000 слов, терминов и фразеологических выражений / Под ред. проф. Л. И Скворцова. 27-е изд., испр. - М.: ООО «Издательство «Мир и Образование», 2013. - 736 с.

27. Основы автоматического управления / Под ред. В. С. Пугачева. - М.: Государственное изд-во физико-математической литературы, 1963. - 646 с. - C. 19.

28. Положение о Министерстве имущественных отношений Российской Федерации: утв. Постановлением Правительства Российской Федерации от 3 июня 2002 г. // Собрание законодательства Российской Федерации, 2002 г. - N 3.

29. Положение о территориальном управлении федерального агентства по управлению государственным имуществом в Ленинградской области: утверждено Приказом Федерального агентства по управлению государственным имуществом от 5 марта 2009 г. N 64 (в ред. приказов Росимущества от 7 августа 2009 г. N 229; от 29 сентября 2010 г. N 263; от 18 ноября 2010 г. N 332).

30. Попондопуло В. Ф. Правовой режим предпринимательства. - СПб.: Изд-во С.-Петербургского университета, 1994. - 208 с.

31. Сморчкова Л. Н. Правовой режим имущества, полученного организациями Пограничной службы Российской Федерации за счет внебюджетных источников: Дис. ... канд. юрид. наук. 20.02.03.

32. Субботкина Е. В. Гражданская правосубъектность военного образовательного учреждения высшего профессионального образования пограничной службы Российской Федерации: Дис. ... канд. юрид. наук. 20.02.03.

33. Токарев Е. И. Организационно-правовые вопросы реализации высвобождаемого военного имущества в Вооруженных Силах Российской Федерации: Дис. ... канд. юрид. наук. 20.02.03.

34. Хомяков А.Ю. Гражданско-правовой статус регионального пограничного управления: Дис. ... канд. юрид. наук. 20.02.03.

35. Ярмак Р. Н. Правовое положение федеральных государственных унитарных предприятий и учреждений Вооруженных Сил Российской Федерации: Дис. ... канд. юрид. наук. 20.02.03.

Статья поступила в редакцию 3 апреля 2018 г. 